\title{
Effect of White Champa Leaf Extract (Plumeria acuminata) on White Fly Eclosion (Aleurolobus barodensis Maskell, Hemiptera; Aleyrodidae) under Laboratory Condition
}

\section{Pengaruh Ekstrak Daun Kamboja Putih (Plumeria acuminata) terhadap Eklosi Cabuk Hitam (Aleurolobus barodensis Maskell, Hemiptera; Aleyrodidae) di Laboratorium}

\author{
Vivin Diana Putri ${ }^{1)}$ and Etik M. Achadian ${ }^{2)}$ \\ 1) Sunan Ampel Islamic University, Surabaya \\ 2) Indonesian Sugar Research Institute, Pasuruan \\ Email: vivindiana23@gmail.com
}

\begin{abstract}
The white fly explosion might be occurred on the flooded fields and lack of nitrogen fertilizer. Some control methods have to be conducted to prevent further losses. The use of biopesticide was known to be easier, cheaper and environmental friendly control methods. Therefore the aim of this experiment was to determine the effect of white champa leaf extract (Plumeria acuminata) as a biopesticide on sugarcane white fly eclosion (Aleurolobus barodensis). Experiment was conducted in the laboratory, using a complete randomized design with 6 treatments of $P$. acuminata leaf extract concentrations, $0 \%$ (control), 10\%, $20 \%, 30 \%, 40 \%$ and $50 \%$, and was replicated 4 times. The results showed that $P$. acuminata leaf extract could be used to control sugarcane white fly. The effective leaf extract concentration was $40 \%$. The results also proved that $P$. acuminata leaf extract killed the white fly pupae instead of delaying their eclosion.
\end{abstract}

Key words: eclosion, white fly, biopesticide

\begin{abstract}
ABSTRAK
Eksplosi serangan cabuk hitam biasanya terjadi pada kebun yang terendam banjir dan kahat hara nitrogen. Pengendalian serangan hama harus dilakukan untuk mencegah kerugian lebih lanjut. Pengendalian dengan pestisida nabati diketahui lebih mudah, murah dan aman terhadap lingkungan. Oleh karena itu percobaan ini bertujuan untuk mengetahui pengaruh ekstrak daun kamboja putih (Plumeria acuminata) terhadap penetasan (eklosi) imago cabuk hitam (Aleurolobus barodensis). Percobaan dilakukan di laboratorium, menggunakan rancangan acak lengkap dengan 6 perlakuan konsentrasi ekstrak daun kamboja putih yaitu 0\% (kontrol), 10\%, 20\%, 30\%, 40\% dan 50\% dan diulang 4 kali. Hasil percobaan menunjukkan ekstrak daun P. acuminata dapat digunakan untuk mengendalikan hama cabuk hitam. Konsentrasi ekstrak daun yang efektif adalah 40\%. Hasil percobaan juga
\end{abstract}


membuktikan bahwa ekstrak daun P. acuminata dapat membunuh pupa cabuk hitam bukan hanya menunda penetasannya.

Kata kunci: eklosi, cabuk hitam, pestisida nabati

\section{INTRODUCTION}

The white fly (Aleurolobus barodensis Maskell, Hemiptera; Aleyrodidae) is considered a minor pest of sugarcane, however it is widely spread throughout sugarcane plantations in Indonesia (Achadian, et al., 2012) and may sometimes cause heavy infestations during wet season especially in January - March. Severe infestations of $A$. barodensis are usually found in flooded plants or in conditions where crops are insufficiently fertilizer by Nitrogen (Bhavani and Rao, 2013; Bhargava et al., 2020).

The $A$. barodensis life cycle categorized as complete metamorphosis. Its life cycle began from eggs, then nymphs, pupae, and eclocated into adult A. barodensis. The nymph phases were divided into 3 instars. First instar nymphs were motile by crawling, while second and third instar nymphs were sessile or immobile. The pupal phase was also called 4 instar nymph (Hamid, 1955). The A. barodensis eclosion usually takes place during the morning. They appeared through the T-shaped slit on the dorsal part of the pupae. During eclosion, the head came out first and its process took about 7 to 9 minutes. After the entire adult body of $A$. barodensis left the pupa, a wing straightening process occurred for 10 to 14 minutes (Shandu \& Singh, 1964). Then adult $A$. barodensis flew, mated and laid their eggs on the new plants.

Heavy infestations by $A$. barodensis have recently been observed in the fields in Pasuruan. The white fly prefers to attack sugarcane varieties with wide dark green leaves. Studies in India stated that severe white fly infestation may result in reduction of cane yield up to $24 \%$ and loss in sugar up to 2.9 units (Bhavani and Rao, 2013). A control must be conducted in order to prevent greater losses. Some control methods were used in suppressing white fly population in some countries such as spraying insecticide (Mohammadi et al., 2017; 2018), cultural control (Bhatti et al., 2019), releasing its parasitoid (Nikpay, 2017; Mohammadi et al., 2019; Bhargava et al., 2020) and biopesticide (Djunaedy et al., 2009).

Biopesticide have a role in pest management being environmental friendly and may offer an alternative to pesticide ((Djunaedy et al., 2009). Plant extracts such as neem (Azadirachta indica), papaya (Carica papaya), lemon grass (Cymbopogon citratus), tobacco (Nicotiana tabacum), white champa (Plumeria acuminata), have been used against a range of agricultural and forestry crop pest species in Indonesia (Sari et al., 2013; Suhartini, et al., 2017; Latumahina, et al., 2021).

$P$. acuminata is a small tree with sparse thick leaves, and white to purplish-red crown flowers. $\quad P$. acuminata leaves contain stigmast-7-enol, lupeol carboxylic acid, lupeol acetate and ursolic acid. The fulvoplumierin, plumericin along with three new compounds isoplumericin, $\beta$-dihydroplumericin and $\beta$ - dihydroplumericinic acid can be isolated from roots. In addition, essential oils in steam distillate contain primary alcohols, geraniol, citronellol, farnesol and phenylethyl alcohol and traces of aldehyde and ketones (Ibanez et al., 2012). $P$. acuminate also contained agoniadins, plumierids, plumeric acid, lipeol, and serotonic acid, saponins, flavonoids, 
polyphenols and alkaloids (Wrasiati, et al., 2011).

The previous study by Utami and Cahyati, (2017) reported that $P$. acuminata leaf extract can be used in controlling Aedes aegypti mosquito. Yuliana and Kadarusno (2016) used P. acuminate leaf extract in controlling house flies (Musca domestica).

This work was conducted to study the effect of $P$. acuminata leaf extracts as a biopesticide on eclosion of white fly (Aleurolobus barodensis), under laboratory condition.

\section{METHODS}

The experiment was conducted at Plant Protection Laboratory of Indonesian Sugar Research Institute, Pasuruan from January to February 2021, with daily temperature $30 \pm$ $2{ }^{\circ} \mathrm{C}$ and relative humidity $70 \pm 5 \%$. The experiment used a Complete Randomized Design with 6 treatments and 4 replications. The treatments were $P$. acuminata leaf extract with the following concentrations:

T1 : control (aquadest)

T2 : P. acuminata leaf extract $10 \%$

T3 : P. acuminata leaf extract $20 \%$

T4 : P. acuminata leaf extract $30 \%$

T5 : P. acuminata leaf extract $40 \%$

T6 : P. acuminata leaf extract $50 \%$

$P$. acuminata leaf extract was made by washing and slicing the leaves into small pieces and left to dry. Dried leaves were then crushed to make a powder. To prepare the leaf extract, 200 grams of leaf powder were dissolved in $400 \mathrm{ml}$ aquadest. The solution was allowed to sit overnight and stirred occasionally. The solution was then filtered and concentrations of 10, 20, 30, 40 and 50\% were prepared. Application was conducted by spraying the solution on sugarcane leaves using a hand sprayer.

This experiment used two $5 \times 5 \mathrm{~cm}$ pieces of white fly infested sugarcane leaves of PSJT 941 variety, placed in petri dishes. To maintain leaf moisture, petri dishes were placed in a plastic tray filled with water as high as $0.5 \mathrm{~cm}$.

Observations were conducted at 24 hours intervals. We observed the number of white fly eclosion from each treatment. Emerged white fly adults were put in the freezer for \pm 30 minutes to make it inactive so that it was easy to calculate. Statistical analysis was carried out using the SPSS software.

\section{RESULT AND DISCUSSION}

The $A$. barodensis eclosion happened in the morning around 7:00 a.m. to 8:30 a.m. They appeared through the T-shaped slit on the dorsal part of the pupae (Figure 1). Sugarcane leaves that were infested by $A$. barodensis appeared yellowing and chlorosis lines along the leaf blade.

Result showed that $P$. acuminata leaf extract application reduced the number of $A$. barodensis eclosion (Tabel 1). Suppression effect could be observed from low to high concentration. But leaf extract concentration of $40 \%$ had the better result at all observation time. The significant effect was begun 2 days after application which was the eclosion number of pupa on these treatments quite different to control. 

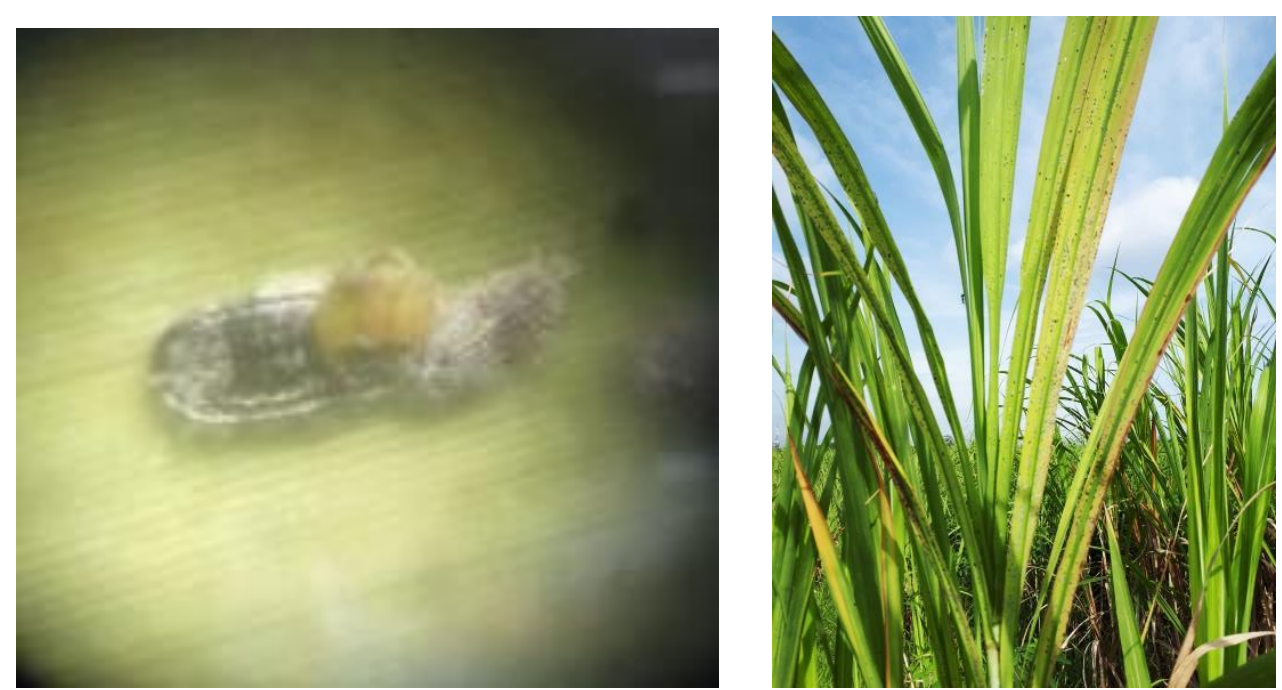

Figure 1. A. barodensis eclosion (left) and infested plants (right) Gambar 1. Eklosi A. barodensis dewasa (kiri), tanaman terserang (kanan)

Tabel 1 . The number of white fly eclosion on 1, 2, 3, 4, and 5 days after biopesticide application

Table 1. Jumlah eklosi cabuk hitam pada pengamatan 1, 2, 3, 4, dan 5 hari setelah aplikasi biopestisida di laboratorium

\begin{tabular}{|c|c|c|c|c|c|}
\hline \multirow{2}{*}{$\begin{array}{l}\text { Treatments } \\
\text { Perlakuan }\end{array}$} & \multicolumn{5}{|c|}{$\begin{array}{l}\text { White fly eclosion numbers on observation day } \\
\text { Jumlah eklosi cabuk hitam pada pengamatan hari ke }\end{array}$} \\
\hline & 1 & 2 & 3 & 4 & 5 \\
\hline $0 \%$ & $11,5 \pm 3,3^{a}$ & $53,25 \pm 0,4^{a}$ & $95 \pm 1,8^{c}$ & $135,75 \pm 2,9^{c}$ & $155,75 \pm 3,3^{b}$ \\
\hline $10 \%$ & $7,5 \pm 1,5^{a}$ & $52,25 \pm 1,5^{a b}$ & $52,75 \pm 1,5^{b c}$ & $52,75 \pm 1,5^{b}$ & $52,75 \pm 1,5^{a}$ \\
\hline $20 \%$ & $5 \pm 1,4^{a}$ & $25,25 \pm 1,5^{a b}$ & $27 \pm 1,5^{a b}$ & $27,75 \pm 1,5^{a b}$ & $28,5 \pm 1,4^{a}$ \\
\hline $30 \%$ & $6,25 \pm 3,1^{a}$ & $20,25 \pm 3,0^{a b}$ & $25,75 \pm 2,8^{a}$ & $31,75 \pm 2,9^{a b}$ & $34,5 \pm 3,1^{a}$ \\
\hline $40 \%$ & $1 \pm 0,8^{a}$ & $8 \pm 1,5^{b}$ & $9,5 \pm 1,1^{a}$ & $12,75 \pm 0,8^{a}$ & $14,25 \pm 0,8^{a}$ \\
\hline $50 \%$ & $1,75 \pm 1,1^{a}$ & $13,75 \pm 0,9^{b}$ & $14,25 \pm 0,9^{a}$ & $15 \pm 1,1^{a}$ & $15 \pm 1,1^{a}$ \\
\hline p-Value & 0,222 & 0,015 & 0.000 & 0,000 & 0,000 \\
\hline
\end{tabular}

Note: Numbers followed by the same letter in one column indicate there is no significant difference between treatments in the Tamhane test $(5 \%)$ and DMRT $(5 \%)$.

Keterangan: Angka yang diikuti oleh huruf yang sama dalam satu kolom menunjukkan tidak ada perbedaan nyata antar perlakuan pada uji Tamhane (5\%) dan DMRT (5\%).

Table 1 and Table 2 showed that P.acuminata leaf extract concentration of $40 \%$ had the highest suppression of eclosion, although there were not significantly different to other concentrations. The interesting result was showed that the P.acuminata leaf extract concentration of $50 \%$ has a lower suppression percentage than that of $40 \%$. It was supposed that P.acuminata leaf extract concentration of $50 \%$ was higher concentrate so that the active substances could not diffuse into the pupa's body. According to Syafina et al. (2020) the active compounds in saturate solution cannot be dissolved optimally. Therefore higher 
concentrate of $P$. acuminata leaf extract did not provide high pupal mortality as well.

Tabel 2. Suppression level (\%) of adult white fly eclosion by $P$. acuminata leaf extracts treatments on day 5

Tabel 1. Tingkat penekanan (\%) eklosi cabuk hitam pada perlakuan ekstrak daun P. acuminata pada hari ke-5

\begin{tabular}{cc}
\hline $\begin{array}{c}\text { Leaf extract } \\
\text { concentration } \\
\text { Konsentrasi ekstrak } \\
\text { daun }\end{array}$ & $\begin{array}{c}\text { Suppression level } \\
(\%) \\
\text { Tingkat } \\
\text { penekanan }(\%)\end{array}$ \\
\hline $10 \%$ & 66,0 \\
$20 \%$ & 81,7 \\
$30 \%$ & 77,8 \\
$40 \%$ & 90,8 \\
$50 \%$ & 90,3 \\
\hline
\end{tabular}

Further observations showed that 5 days after leaf extract application there was only a bit number eclosion of white fly. In 7 days after biopesticide application there was no eclosion occurred in the biopesticide treatment but the eclosion still occurred in the control treatment. This showed that $P$. acuminata leaf extract affects eclosion by killing the pupae, not by delaying the eclosion time. However we did not observe which compounds of $P$. acuminata leaf extract caused the death of pupae.

\section{CONCLUSION}

The white champa ( $P$. acuminata) leaf extract affected the eclosion of white fly ( $A$. barodensis) by killing its pupae in the laboratory. The most significant concentration was $40 \%$. Further experiment has to be conducted to examine its effectivity in the fields.

\section{ACKNOWLEDGEMENT}

The authors would like to thank to Hesti Amelia, Nike Nada Puspita and M. Imron for their help during conducting this experiment.

\section{REFERENCES}

Achadian, E. M., Kristini, A., Putra, L. K., dan Dianpratiwi, T. (2012) 'HamaHama Pertanaman Tebu di Jawa: Sebaran, Intensitas Serangan dan Keberadaan Musuh Alami Hama', $M P G, 48(2)$ : 73-83.

Bhatti, I.B., Khatri, I., Rustamani, M.A. and Sultana, R. (2019) 'Effect of Different Control Methods on the Population of Sugarcane Whitefly (Aleurolobus Barodensis Mask.)', Pakistan Journal of Agricultural Research, 32(4), pp. 595-600.

Bhavani, B. and Rao, C. H. V. N. (2013) 'Management of Sugarcane White Fly ( Aleurolobus Barodensis Mask .) in North Coastal Districts of Andhra Pradesh, India', 2(9): 112-115.

Bhargava, C.N., Matti, P., Tippannavar, P.S. \& Patil, S.B. (2020) 'First report on new record of natural enemy complex on sugarcane whitefly Aleurolobus barodensis Mask . in Southern India', Journal of Entomology and Zoology Studies, 8(3): 1126-1128.

Djunaedy, A. et al. (2009) 'Biopestisida Sebagai Pengendali Organisme Pengganggu Tanaman ( Opt ) Yang Ramah Lingkungan', Embryo, 6(1): 8895.

Hamid, M. S. (1955) 'Morphology and Biology of The Sugarcane Whitefly, Aleurolobus barodensis Mask., in India', Entomological Society of India, 4: 1-34. 
Ibanez, S., Gallet, C. and Després, L. (2012) 'Plant Insecticidal Toxins in Ecological Networks', Toxins, 4: 228-243.

Latumahina, F. S., Mardiatmoko, G., \& Tjoa, M. (2021) Penggunaan Biopestisida Nabati untuk Pengendalian Hama Tanaman Kehutanan (Peluang Pengembangan Kelompok Tani). Adab, Indramayu.

Mohammadi, P.K, Ziaee, M. and Nikpay, A. (2017) 'Insecticides from Different Classes Impact on Neomaskellia andropogonis Population Under Sugarcane Field Conditions', Sugar Tech, 19(6): 623-631. doi: 10.1007/s12355-017-0532-8.

Mohammadi, P.K, Ziaee, M. and Nikpay, A. (2018) 'Studies on survival of sugarcane whitefly, Neomaskellia andropogonis on two sugarcane varieties treated with various insecticides', Journal of Entomological Society of Iran, 38(2): 219-234.

Mohammadi, P.K, Ziaee, M. and Nikpay, A. (2019) 'Sugarcane whiteflies control techniques in south asia: A review with special reference to iran sugar industries', Agrica, 8(2): 70. doi: 10.5958/2394-448x.2020.00002.4.

Nikpay, A. (2017) 'Damage Assessment of Sugarcane Whitefly Neomaskellia andropogonis Corbett and Population Dynamics on Seven Commercial Varieties in Southwest of Iran', Sugar Tech, 19(2): 198-205. doi: 10.1007/s12355-016-0451-0.

Sari, M., Lubis, L., \& Pangestiningsih, Y. Y (2013) 'Uji Efektivitas beberapa Insektisida Nabati untuk Mengendalikan Ulat Grayak (Spodoptera litura F.) (Lepidoptera:
Noctuidae) di Laboratorium', Jurnal Agroekoteknologi Universitas Sumatera Utara, 1(3): 560-569.

Shandu, J. S., Singh, S. (1964) 'Studies on the Control of Sugarcane Whitefly, Aleurolobus barodensis Mask., in Punjab', Indian J. Sug. Res. Dev., 8: 361-366.

Suhartini, S., Suryadarma, P., \& Budiwati, B. (2017) 'Pemanfaatan Pestisida Nabati Pada Pengendalian Hama Plutella Xylostella Tanaman Sawi ( Brassica Juncea L .) Menuju Pertanian Ramah Lingkungan', Jurnal Sains Dasar, 6(1): 36-43.

Syafina, B. S. and Zulfa, F. (2020) 'Uji Efektivitas Cuka Apel Terhadap Pertumbuhan Malassezia furfur Secara In Vitro Dengan Metode Difusi Perforasi', Seminar Nasional Riset Kedokteran (SENSORIK): 202-207.

Utami, I.W., \& Cahyati, H. (2017) 'Potensi Ekstrak Daun Kamboja Sebagai Insektisida Terhadap Nyamuk Aedes Aegypti', Higeia: Journal Of Public Health, 1(1): 22-28.

Wrasiati, L. P., Hartati, A., \& Yuarini, D. A. A. (2011) 'Kandungan Senyawa Bioaktif Dan Karakteristik Sensoris Ekstrak Simplisia Bunga Kamboja ( Plumeria Sp . ) Bioactive Compounds And Sensory Charasteristics Of Simplisia Extract Of Frangipani ( Plumeria sp .)', Jurnal Biologi, 15(2): 39-43.

Yuliana, V. and Kadarusno, A. H. (2016) 'Aplikasi Penyemprotan Perasan Daun Kamboja (Plumeria acuminata) Terhadap Kematian Lalat Rumah (Musca domestica)', Jurnal Kesehatan Lingkungan, 13(1): 229-305. 